\title{
Pericardita tuberculoasă, o patologie actuală în pediatrie - prezentare de caz şi date din literatură
}

\author{
Lorena Elena Meliț', Cristina Oana Mărginean' ${ }^{1}$, George Rolea², Vlăduț Ştefan Săsăran ${ }^{3}$, \\ Cristian Dan Mărginean ${ }^{3}$ \\ ${ }^{1}$ Clinica Pediatrie I, Târgu-Mureş, România \\ ${ }^{2}$ Clinica Obstetrică şi Ginecologie I, Târgu-Mureş, România \\ 3Universitatea de Medicină şi Farmacie, Târgu-Mureş, România
}

\begin{abstract}
REZUMAT
Tuberculoza este una din cele mai frecvente patologii infecţioase, reprezând o problemă majoră de sănătate publică globală, cu incidenţă crescută la vârsta pediatrică. Prezentăm cazul unui pacient în vârstă de 15 ani, care a fost internat în clinica noastră pentru febră, stare de rău, vărsături, tuse productivă, ameţeli şi dureri toracice. Antecedentele personale patologice au subliniat faptul că pacientul a mai prezentat dureri toracice în urmă cu aproximativ 6 luni, care au fost interpretate ca nevralgie intercostală. Analizele de laborator au evidenţiat: leucocitoză, neutrofilie, monocitoză, probe inflamatorii crescute şi hiponatremie. Ecocardiografia a evidenţiat pericardită lichidiană. În ciuda tratamentului antibiotic cu spectru larg, cantitatea de lichid pericardic a crescut, astfel că s-a efectuat puncţie pericardică. Datorită evoluţiei lent favorabile şi a rezultatelor testelor uzuale negative din lichidul de puncţie, am efectuat de asemenea teste bazate pe reacţia în lanţ a polimerazei, care au identificat ADN-ul bacterian în lichid stabilind astfel diagnosticul de pericardită tuberculoasă. Particularitatea cazului constă în diagnosticarea unei pericardite TBC la un adolescent de sex masculin, în vârstă de 15 ani, care a mai prezentat dureri toracice în antecedentele personale recente, doar pe baza identificării ADN-ului M. tuberculosis din lichidul pericardic, în lipsa altor teste pozitive pentru această infecţie.
\end{abstract}

Cuvinte cheie: pericardită, pediatrie, tuberculoză
Abrevieri
Hb: hemoglobină
PCR: proteina C-reactivă
Htc: hematocrit
TA: tensiune arterială
G: greutate
I: înălțime
TBC: tuberculoză
VEM: volum eritrocitar mediu
M. tuberculosis: Mycobacterium tuberculosis VSH: viteza de sedimentare a hematiilor
OMS: Organizația Mondială a Sănătății

\section{INTRODUCERE}

Tuberculoza este una dintre cele mai frecvente patologii infecțioase din lume, fiind cunoscută de mai bine de 4.000 de ani. Termenul de tuberculoză a fost introdus pentru prima dată în anul 1830 de către Schönlein şi provine de la termenul englezesc „tubercle“, care înseamnă leziune de consumpție. Complexul Mycobacterium tuberculosis (M. tuberculosis) cuprinde 5 tipuri de bacterii, şi anume: $M$. tuberculosis, Mycobacterium africanum, Mycobacterium bovis, Mycobacterium microti şi Mycobacterium carnetti, însă $M$. tuberculosis este cea care cauzează cel mai frecvent tuberculoza la specia umană. Mycobacteriile cresc lent pe medii de cultură specifice, precum Löwenstein-Jensen, la temperaturi între 37 şi $41^{\circ} \mathrm{C}$, izolarea pe medii durând între 3 şi 6 săptămâni, iar testarea susceptibilităţii la tuberculostatice necesită încă 2-4 săptămâni. 
Transmiterea se face pe cale aeriană. Organizația Mondială a Sănătătii susține că tuberculoza (TBC) este a doua cauză de mortalitate infecțioasă la nivel mondial (după HIV) şi că aproximativ o treime din populația globului este infectată cu M. tuberculosis, iar 95\% dintre cazuri aparțin țărilor subdezvoltate (1). De asemenea, OMS afirmă că în 2013 au fost identificate aproximativ 550.000 de cazuri de TBC la copii, care au dus la 80.000 de decese la nivel mondial la copiii fără infecție HIV asociată (1).

Pericardita tuberculoasă este rară, apărând în aproximativ $0,5-4 \%$ din cazurile de TBC la copii, însă este cea mai frecventă formă de TBC cardiacă, fiind rezultatul invaziei directe a vaselor limfatice de la nivelul limfonodulilor subcarinali (1). Simptomatologia este nespecifică şi poate include: febră, stare de rău, scădere ponderală şi durere toracică, puțin frecventă la copii (1). Aspectul lichidului pericardic este sero-fibrinos sau hemoragic, iar diagnosticul este foarte dificil de stabilit. Examenul microscopic pentru evidențierea bacilului Koch în lichidul de puncție pericardică este cel mai adesea negativ, iar cultura este pozitivă în 30-70\% dintre cazuri (1). Cu toate acestea, cultura din biopsia pericardică poate prezenta o sensibilitate de diagnostic mai crescută, iar identificarea granuloamelor sugerează adesea diagnosticul pozitiv (1). Testele de tip ,polymerase chain reaction“ identifică ADNul bacterian în diferitele probe biologice, fiind însă o metodă costisitoare, care poate fi efectuată şi din sânge când probele biologice specifice locului infecției nu sunt disponibile, însă cu sensibilitate scăzută (2). Reacția la tuberculină (IDR) rămâne una dintre cele mai simple şi utile metode de diagnostic. Tratamentul TBC este foarte complex şi de durată foarte îndelungată, necesitând monitorizare atentă atât din partea familiei cât şi a medicului. Astfel, prognosticul TBC depinde în mare măsură de complianţă, însă şi potențialele complicații.

\section{PREZENTARE DE CAZ}

Prezentăm cazul unui pacient în vârstă de 15 ani, internat în clinica noastră pentru febră, tuse productivă, rinoree, dureri toracice anterioare, amețeli şi vărsături. Antecedentele heredocolaterale sunt nesemnificative pentru patologia actuală. Antecedentele personale patologice subliniază faptul că pacientul a mai prezentat dureri toracice în urmă cu aproximativ 6 luni, pentru care s-a prezentat la serviciul de urgență, unde au fost interpretate ca nevralgie intercostală. Boala actuală a debutat în urmă cu aproximativ o săptămână anterior internării cu febră $\left(38^{\circ} \mathrm{C}\right)$, tuse iniţial seacă, ulterior productivă, obstrucție nazală, la care în urmă cu 2 zile pacientul a asociat dureri toracice anterioare intense, accentuate de inspir, amețeli şi vărsături, fiind astfel internat în clinica noastră.

Examenul obiectiv efectuat la internare a evidențiat următoarele elemente patologice: stare generală influențată, ortopnee, țesut conjunctiv adipos foarte bine reprezentat, limbă saburală, faringe hiperemic, amigdale hipertrofice, tuse productivă, obstrucție nazală, zgomote cardiace uşor estompate, hipotensiune arterială (TA: $86 / 49 \mathrm{mmHg}$ ), saturație $\mathrm{O}_{2} 92 \%$, G: $85 \mathrm{~kg}$, Î: $167 \mathrm{~cm}$.

Hemoleucograma efectuată în momentul internării a arătat: leucocitoză $(13.670 / \mu \mathrm{L})$, neutrofilie $(9.880 / \mu \mathrm{L})$, monocitoză $(2.480 / \mu \mathrm{L})$, şi anemie $(\mathrm{Hb}$ 11,4 g/dL, Htc 33.9\%, VEM 77,8 fL). Analizele biochimice au evidențiat hiponatremie (126,9 $\mathrm{mmol} / \mathrm{L}$ ), iar probele inflamatorii au fost crescute (PCR 136 mg/l, VSH $105 \mathrm{~mm} / \mathrm{h}$ ). S-a efectuat de asemenea radiografie toracică care a pus în evidență un aspect sugestiv pentru pneumonie interstițială şi ecocardiografie, care a arătat o colecție lichidiană ce coafează cordul de aproximativ $1,7 \mathrm{~cm}$ anterior de ventriculul drept şi $2,3 \mathrm{~cm}$ posterior de ventriculul stâng, fără semne de tamponadă cardiacă, recomandând tratament diuretic (Furosemid şi Spironolactonă) asociat cu perfuzie pentru echilibrarea hiponatremiei. Hemocultura a fost negativă. S-au efectuat de asemenea teste serologice specifice, excluzându-se o patologie autoimună. Astfel, am administrat tratament antibiotic, cefalosporină de generația a III-a (Cefort) asociată cu aminoglicozid (Amikacină) timp de 5 zile, însă febra a persistat, astfel că am schimbat schema antibiotică administrând Meropenem cu Vancomicină, precum şi antimicotice şi simptomatice. În ciuda tratamentului diuretic, ecocardiografia efectuată în ziua a 7-a de la internare a evidențiat creşterea cantității de lichid pericardic, astfel că s-a efectuat puncție pericardică şi s-au evacuat aproximativ $150 \mathrm{ml}$ lichid serosangvinolent. Examenul microbiologic din lichidul pericardic a fost negativ, precum şi examenul microscopic pentru decelarea bacilului Koch, iar examenul anatomopatologic a evidențiat doar prezența 
de celule inflamatorii. În ziua a 10-a de la internare, pacientul a prezentat reapariția febrei, astfel că carbapenema este inlocuită cu o fluorochinolonă (Levofloxacină), efectuându-se de asemenea examen RMN cardiac, care a arătată prezenţa unui tromb retrocardiac. După iniţierea tratamentului menționat anterior, evoluția a fost favorabilă, astfel că am efectuat testare PCR din lichidul pericardic, care a evidențiat prezența Mycobacterium tuberculosis, astfel că pacientul a fost transferat în secția de pneumoftiziologie în vederea administrării unui tratament specific şi a unei monitorizări adecvate.

Particularitatea cazului constă în diagnosticarea unei pericardite TBC la un adolescent de sex masculin, în vârstă de 16 ani, care a mai prezentat dureri toracice în antecedentele personale recente, doar pe baza identificării ADN-ului M. tuberculoris din lichidul pericardic, în lipsa altor teste pozitive pentru această infecție.

\section{DISCUTुII}

Tuberculoza este o problemă majoră de sănătate publică la nivelul întregului glob. La vârsta pediatrică, mortalitatea cea mai mare este întâlnită la copiii sub 5 ani, care nu primesc tratament precoce din cauza dificultăților legate de stabilirea diagnosticului, precum şi la cei cu coinfecție HIV, în ciuda tratamentului corespunzător (3). În afara faptului că diagnosticul de TBC este foarte dificil de stabilit în cazul copiilor cu vârsta sub 5 ani, aceştia reprezintă o categorie cu risc crescut şi din cauza susceptibilității crescute de a dezvolta meningită TBC $(4,5)$. Un studiu recent a arătat că aproximativ 19,3\% dintre copiii cu meningită TBC vor muri, iar $53,9 \%$ dintre cei care vor supraviețui vor prezenta sechele neurologice pe termen lung (6). În România, incidența generală a TBC a scăzut progresiv, de

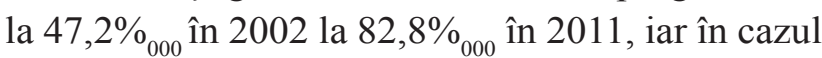
copiilor, în aceeaşi perioadă, de la 47,2\% $\%_{000}(1.784$ de cazuri) la 23,6\% ${ }_{000}$ (766 de cazuri) (7).

Pericardita TBC este o patologie rară la copii, care implică multiple dificultăţi legate de stabilirea diagnosticului pozitiv. Simptomatologia pericarditei TBC la copii este nespecifică incluzând: febră, stare de rău, scădere ponderală sau durere toracică, care însă este puțin frecventă la copii (1). Pacientul prezentat mai sus a prezentat febră, stare de rău, însă fără scădere ponderală, el fiind de altfel un adolescent obez. Cu toate că în literatură durerea toracică este raportată ca fiind rară în cazul pericarditei TBC la copii, pacientul nostru a prezentat, de asemenea, pe lângă cele menționate anterior, dureri toracice anterioare intense. Analizele de laborator precum şi examinările imagistice sunt adesea nespecifice în cazul copiilor care suferă de TBC. Două teste relativ frecvent utilizate în diagnosticarea TBC sunt testul la tuberculină şi testele pe baza de interferon-gamma. Într-un studiu efectuat pe 109 copii marocani, testele pe bază de eliberare de interferon-gamma au prezentat sensibilitate şi specificitate mai mare în comparație cu testul la tuberculină, fiind astfel recomandată coroborarea rezultatelor acestor două teste în vederea stabilirii unui diagnostic cât mai exact (8). Testele bazate pe reacția în lanț a polimerazei identifică atât $\mathrm{ADN}$-ul bacterian din diferitele probe biologice precum şi prezența caracterelor de rezistență bacteriană. Conform unui studiu recent, aceste teste identifică $M$. tuberculosis şi în cazurile în care cultura este negativă, ducând la concluzia că sunt probabil cele mai sensibile şi specifice teste utile pentru a creşte rata de detecție (9). Similar, în cazul pacientului prezentat de noi, prezența $M$. tuberculosis a fost evidențiată de asemenea doar cu ajutorul reacției în lanț a polimerazei. În plus, în afara incidenței foarte crescute a acestei patologii la nivel mondial, creşterea incidenței cazurilor de TBC multidrog-rezistente (MDR) este un alt fapt îngrijorător, fiind definite ca TBC cauzată de tulpini de $M$. tuberculosis rezistente la izoniazidă şi rifampicină (3). Un review recent a estimat că aproximativ 32.000 de copii sunt afectați de TBC MDR (3). Tuberculoza latentă este o altă entitate medicală care merită atenție crescută din partea medicului pediatru (10), deoarece prevalența anulă a acesteia la copii este de aproximativ 97 milioane (11).

\section{CONCLUZII}

În ciuda incidenței scăzute la vârsta pediatrică, pericardita $\mathrm{TBC}$ rămâne o provocare din cauza simptomatologiei nespecifice la această categorie de vârstă şi a dificultăților legate de stabilirea diagnosituclui pozitiv şi a instituirii tratamentului adecvat. $\mathrm{Cu}$ toate acestea, prognosticul este unul favorabil în lipsa dezvoltării complicațiilor. 